\title{
PEMANFAATAN MEDIA PEMBELAJARAN AUDIO VISUAL DALAM MENGEMBANGKAN MOTIVASI BELAJAR SISWA PADA MATA PELAJARAN IPS TERPADU
}

\author{
Muhammad Ikhsan Mu' $\operatorname{minin}^{1}$, Muhammad Syafiq Humaisi ${ }^{2}$ \\ ${ }^{1}$ Institut Agama Islam Negeri Ponorogo \\ Ikhsanrocket63@gmail.com \\ ${ }^{2}$ Institut Agama Islam Negeri Ponorogo \\ syafiqhumaisi@gmail.com
}

\begin{abstract}
ABSTRAK
Penelitian ini dilatar belakangi oleh keingin tahuan peneliti dalam pemanfaatan media pembelajaran audio visual yang ada di SMP Negeri 1 Jenangan, Media audio visual adalah media yang mempunyai unsur suara dan unsur gambar, Jenis media ini mampu memberikan pengalaman belajar yang lebih baik karena meliputi suara dan gambar. Untuk menunjang kesuksesan media ini haruslah dengan sarana dan prasarana yang memadai dan layak untuk difungsikan. Sejumlah peralatan yang dipakai oleh para guru dalam menyampaikan konsep, gagasan dan pengalaman yang ditangkap oleh indera pandang dan pendengaran berdasarkan pengertian-pengertian yang telah diberikan. Pemanfaatan media pembelajaran berbasis audio visual didasari adanya masalah rendahnya motivasi belajar peserta didik dalam proses pembelajaran yang menyebabkan peserta didik kurang aktif dalam memperhatikan pelajaran. Penelitian ini menggunakan pendekatan kualitatif dengan jenis penelitian studi kasus. Menggunakan studi kasus karena dalam penelitian, peneliti menekankan pada penjelasan kasus, yakni pemanfaatan media audio visual pada mata pelajaran IPS Terpadu di SMP Negeri 1 Jenangan. Data yang didapatkan dengan teknik pengumpulan data observasi, wawancara dan dokumentasi.
\end{abstract}

Kata Kunci: Media Pembelajaran Audio Visual, Motivasi Belajar.

\section{ABSTRACT}

This research was motivated by the researcher's curiosity in the use of audiovisual learning media at SMP Negeri 1 Jenang. Audio-visual media is media that has sound and image elements. This type of media is able to provide a better learning experience because it includes sound and images. . To support the success of this media, it must be with adequate facilities and infrastructure that are appropriate to function. A number of tools used by teachers in conveying concepts, ideas and experiences that are captured by the sense of sight and hearing based on the meanings that have been given. The use of audio-visual based learning media is based on the problem of low learning motivation of students in the learning process which causes students to be less active in paying attention to lessons. This research uses a qualitative approach with the type of case study research. Using case studies because in research, researchers emphasize case explanations, namely the use of audio-visual media in Integrated Social Studies subjects at SMP Negeri 1 Jenang. The data obtained by using observation data collection techniques, interviews and documentation.

Keywords: Audio Visual Learning Media, Learning Motivation. 
JIIPSI: Jurnal Ilmiah Ilmu Pengetahuan Sosial Indonesia Nomor 1 Volume 1 Tahun 2021, hal 1-12

\section{PENDAHULUAN}

Dalam pembelajaran dewasa ini kita memasuki era dunia media, dimana kegiatan pembelajaran menuntut dikuranginya metode ceramah dan diganti dengan pemakaian banyak media. Jika mengacu pada perkembangan kurikulum saat ini, peserta didik tidak hanya berperan sebagai penerima pesan namun juga sebagai penyampai pesan. Namun fakta di lapangan berbicara berbeda kegiatan pembelajaran masih disampaikan dengan cara konvensional yang hanya dengan ceramah tanpa pemanfaatan media.

Didalam kegiatan pembelajaran terdapat 5 komponen yang penting dalam kegiatan pembelajaran yaitu tujuan, materi, metode, media, dan evaluasi pembelajaran. ${ }^{1}$ Dalam kegiatan pembelajaran, kelima komponen ini sangat mempengaruhi satu dan lainnya. Seperti misalnya dalam pemilihan metode harus disesuaikan dengan media pembelajaran yang akan kita gunakan untuk menyampaikan materi kepada siswa sesuai dengan kebutuhan dan karakteristik peserta didik yang bersangkutan.

Sebagai salah satu komponen pembelajaran. Media tidak bisa luput dari pembahasan sistem pembelajaran secara menyeluruh. ${ }^{2}$ Pemanfaatan media seharusnya merupakan bagian yang harus mendapat perhatian pendidik dan peserta didik dalam setiap kegiatan pembelajaran. Namun kenyataanya bagian inilah yang masih sering terabaikan dengan berbagai alasan. Alasan yang sering muncul antara lain: terbatasnya waktu untuk membuat persiapan mengajar, sulitnya mencari media yang tepat, tidak tersedianya biaya, dll.

Secara umum, media pembelajaran berarti segala sesuatu yang dapat digunakan untuk menyalurkan bahan pembelajaran sehingga dapat merangsang perhatian, minat, pikiran, dan perasaan siswa untuk mencapai tujuan pembelajaran. ${ }^{3}$ Media pembelajaran memiliki peran yang penting sebagai salah satu komponen sistem pembelajaran. Tanpa media pembelajaran, proses pembelajaran sebagai proses komunikasi tidak dapat berlangsung secara maksimal. Hubungan komunikasi antara guru dan peserta didik akan lebih baik dan efisien jika menggunakan media. Media pembelajaran memerlukan peralatan untuk penyajiannya

Ketercapaian tujuan pembelajaran dipengaruhi oleh berbagai aspek, antara lain aspek guru, siswa, ketersediaan sarana-prasarana, penggunaan sumber belajar yang variatif, penerapan metode pembelajaran yang tidak monoton, serta penggunaan media yang menarik. Kemajuan zaman yang diiringi oleh kecanggihan teknologi mendukung penggunaan media yang bervariasi dalam pembelajaran. Permasalahan yang sering muncul dalam pembelajaran adalah adanya keterbatasan ketrampilan guru untuk menggunakan media, keterbatasan sarana prasarana yang tersedia di sekolah, dan juga keterbatasan ketersediaan

\footnotetext{
${ }^{1}$ Nurul Audie, "Peran Media Pembelajaran Meningkatkan Hasil Belajar Peserta Didik", Jurnal Universitas Sultan Ageng Tirtayasa, 2019, 587.

2 Iwan Falahudin, "Pemanfaatan Media Pembelajaran", Jurnal Lingkar Widyaiswara, 4 (Oktober-Desember, 2014), 104.

${ }^{3}$ Khanifatul, Pembelajaran Inovatif (Jogjakarta: AR-Ruzz Media, 2017), 30.
} 
media pembelajaran itu sendiri. Pembelajaran pada dasarnya adalah proses komunikasi yang dilakukan untuk penyampaian informasi dari guru kepada siswa, oleh karena itu media pembelajaran menempati posisi penting sebagai salah satu sistem pembelajaran.

Media pembelajaran memiliki peranan penting dalam menunjang kualitas proses belajar mengajar. Media juga dapat menjadikan pembelajaran lebih menarik dan menyenangkan. Salah satu media pembelajaran yang sedang berkembang saat ini adalah media audio visual.

Asyhar mendefinisikan bahwa media audio visual adalah jenis media yang digunakan dalam kegiatan pembelajaran dengan melibatkan pendengaran dan penglihatan sekaligus dalam satu proses atau kegiatan. Pesan dan informasi yang dapat disalurkan melalui media ini dapat berupa pesan verbal dan nonverbal yang mengandalkan baik penglihatan maupun pendengaran. Beberapa contoh media audio visual adalah film, video, program TV dan lain-lain. ${ }^{4}$

Dengan perkembangan zaman yang terjadi pada saat ini sangatlah pesat dan sebagaimana dengan tugas guru harus dituntut kreatif untuk memotivasi siswa dalam belajar dengan menyenangkan dan tidak membosankan serta dapat memudahkan siswa dalam memahami materi yang diajarkan oleh guru. Salah satunya yaitu dengan menggunakan media pembelajaran audio visual yang mana akan mempermudah siswa dalam memehami materi pembelajaran, khususnya dalam pembelajaran IPS Terpadu penggunaan media pembelajaran audio visual sangatlah diperlukan karena Mata pelajaran IPS merupakan mata pelajaran integrasi dari mata pelajaran Sejarah, Geografi, dan Ekonomi serta mata pelajaran ilmu sosial lainnya yang dalam materinya memerlukan keterpaduan.

Akan tetapi kenyaataan di lapangan IPS masih di ajarkan secara parsial atau terpisah seperti sejarah, ekonomi, sosiologi dan geografi. Dalam proses pembelajaran IPS guru juga kurang dalam mengembangkan kegiatan pembelajaran yang inovatif dan menarik. Guru masih menggunakan model konvensional dan tidak bervariasi yang membuat siswa bosan dan jenuh terhadap mata pelajaran IPS Terpadu. Hal itu terlihat ketika siswa mengikuti pelajaran kurang serius, tidak memperhatikan saat guru menjelaskan, ribut sendiri, cenderung main-main di kelas, dan tidak ingin bertanya mengenai materi yang belum dipahami. Indikasi tersebut menunjukkan kurangnya motivasi belajar siswa dalam mengikuti pelajaran di kelas. Guru sering menggunakan media yang telah tersedia yaitu textbook, selain itu metode ceramah masih mendominasi dalam proses pembelajaran sehingga model pembelajaran cenderung berpusat pada guru. $^{5}$

Media audio visual bertujuan untuk memberikan pengaruh dalam menunjang interaksi pembelajaran yang dilakukan oleh guru dan siswa di dalam kelas. Peran

\footnotetext{
${ }^{4}$ Moh Syaiful RosyidEtall, Ragam Media Pembelajaran (Malang: Literasi Nusantara, 2019), 78.

${ }^{5}$ Dendi Tri Suarno, Sukirno, "Pengembangan Media Pembelajaran IPS dengan Tema Pemanfaatan dan Pelestarian Sungai untuk Siswa Kelas VII SMP," Harmoni Sosial, 2 (September, 2015), 117.
} 
JIIPSI: Jurnal Ilmiah Ilmu Pengetahuan Sosial Indonesia Nomor 1 Volume 1 Tahun 2021, hal 1-12

guru sebagai penyampai pesan dalam bentuk materi, akan lebih mudah menyampaikan materinya kepada siswa sebagai penerima pesan. Selain itu, penggunaan media audio visual juga dapat mendukung terlatihnya kebiasaan dalam penggunaan IPTEK dalam dunia pendidikan yang terus berkembang, agar wawasan tentang pendidikan menjadi lebih luas. ${ }^{6}$

Pentingnya pemanfaatan media audio visual sebagai salah satu sumber belajar siswa dalam Pembelajaran IPS Terpadu yang berlangsung di dalam kelas dengan memanfaatkan media yang sesuai, dapat memacu kreativitas dan antusias siswa dalam mengikuti pembelajaran. Pemanfaatan media belajar yang relevan dengan materi belajar, juga dapat memberikan pengalaman belajar yang sangat dibutuhkan siswa dalam mengonstruksi sebuah pengetahuan soaial. Adapun media audio visual dipilih berdasarkan kenyataan di lapangan bahwa konsep belajar pada dasarnya mengonstruksi lingkungannya. Seringkali saat ini kita jumpai, bahwa kebiasaan bercerita secara lisan lebih diminati oleh siswa dari pada secara tertulis. Pada akhirnya, pemanfaatan media audio visual yang sudah ada didalam kelas saat ini kurang maksimal dalam pembelajaran.

Hasil penelitian Wahidmurni menunjukkan prioritas permasalahan yang dihadapi guru dalam melaksanakan pembelajaran mata pelajaran IPS secara terpadu dengan menggunakan tema adalah (1) kurangnya pemahaman tentang cara mengembangkan materi IPS secara terpadu, (2) kurangnya pemahaman tentang konsep pembelajaran IPS terpadu, (3) ketersediaan sumber belajar (literatur) di madrasah, (4) media pembelajaran yang terbatas, (5) kemampuan untuk merencanakan pembelajaran IPS terpadu, (6) kemampuan dalam menerapkan metode dan teknik pembelajaran, (7) kemampuan dalam melaksanakan penilaian pembelajaran, (8) kemampuan guru dalam menyampaikan informasi, (9) kemampuan siswa dalam menyampaikan pendapat, (10) kondisi kelas kurang kondusif, dan (11) komunikasi antar guru IPS terbatas. ${ }^{7}$

Berdasarkan observasi awal yang dilakukan di SMP Negeri 1 Jenangan diperoleh inforamasi bahwa porses pembelajaran IPS banyak ditemukan siswa yang ngobrol sendiri, bergurau, melamun, dan ada pula yang keluar kelas pada saat proses pembelajaran berlangsung ketika guru sedang menerangkan materi di kelas menggunakan metode ceramah, tanya jawab dan diskusi. Tetapi dalam proses pelaksanaan pembelajaran dikelas guru masih kurang dalam memvariasikan sebuah metode dalam proses pembelajaran karena guru mengajar hanya menggunakan metode diskusi dan ceramah, sehingga siswa merasa bosan dalam mengikuti proses pembelajaran. Pada prosesnya pembelajarannya pun guru masih bersifat menonton, guru hanya mengandalkan sumber dari buku sebenarnya media juga sudah dimanfaatkan tetapi masih kurang maksimal seperti proyektor maupun media yang lainnya pada saat proses pembelajaran berlangsung. Tetapi masih ada saja siswa yang tidak berperan aktif, dan tidak mau mengungkapkan

\footnotetext{
${ }^{6}$ Moh Syaiful RosyidEtall, Ragam Media Pembelajaran, 82.

${ }^{7}$ Wahidmurni, Metodologi Pembelajaran IPS (Yogyakarta: AR-Ruzz Media, 2017), 27.
} 
pendapatnya dalam suatu proses pembelajaran tersebut. Sehingga kurangnya motivasi siswa dalam pembelajaran terutama pembelajaran IPS Terpadu.

Penyelidikan literatur yang dilakukan Day dan Back, menyimpulkan bahwa penyajian yang menggunakan audio dan visual memberikan pengetahuan yang lebih banyak daripada hanya menggunakan salah satu dari dua indera tersebut. Ivor K. Davies mengemukakan tiga kesimpulan dari penelitiannya tentang audio visual: (1) siswa memang dapat belajar dari alat bantu audio visual, (2) besarnya jumlah hasil belajar tergantung dari ketepatan audio visual untuk tujuan belajar, dan (3) belajar dengan alat bantu audio visual dapat ditingkatkan secara langsung dan dianjurkan oleh guru. Dari penelitian tersebut menunjukkan bahwa penggunaan bahan ajar audio visual banyak kegunaannya bagi siswa dan kegiatan akan menghasilkan performa yang optimal jika bahan ajar audio visual digunakan dengan tepat. ${ }^{8}$

SMP Negeri 1 Jenangan sudah menerapkan kurikulum 2013, ketika sebuah sekolah sudah menerapkan kurikulum 2013 maka seorang guru dalam proses belajar mengajar juga harus sudah mampu menggunakan media pembelajaran dalam mengajar agar peserta didik merasa termotivasi untuk belajar. Sekolah ini, dalam pembelajarannya khususnya pada mata pelajaran Ilmu Pengetahuan Sosial Terpadu sudah menggunakan media pembelajaran audio visual yang dapat dilihat dari Rencana pelaksanaan Pembelajaran (RPP). Berangkat dari berbagai hal tersebut, peneliti ingin mengetahui pemanfaatan media pembelajaran audio visual yang dilakukan guru Pendidikan IPS di SMP Negeri 1 Jenangan dalam mengembangkan Motivasi belajar siswa pada mata pelajaran Ilmu Pengetahuan Sosial Terpadu.

Berawal dari hal tersebut peneliti terdorong untuk mengangkat sebuah judul Skripsi yang berjudul "Pemanfaatan Media Pembelajaran Audio Visual Dalam Mengembangkan Motivasi Belajar Siswa Pada Mata Pelajaran IPS terpadu (Studi Kasus di SMPN 1 Jenangan)"

Sesuai dengan latar belakang masalah dan rumusan masalah yang telah dikemukakan maka tujuan penelitian yang ingin dicapai adalah:

1. Untuk mengetahui Bagaimana proses Pemanfaatan Media pembelajaran Audio Visual dalam mengembangkan motivasi belajar pada mata pelajaran IPS Terpadu di SMP Negeri 1 Jenangan.

2. Untuk mengetahui Bagaimana implikasi dari Media Pembelajaran Audio Visual dalam mengembangkan motivasi belajar pada mata pelajaran IPS Terpadu di SMP Negeri 1 Jenangan.

Adapun Manfaat dalam Penelitian ini diharapkan dapat memberikan manfaat kepada semua yang membacanya, baik dari kalangan akademisi maupun kalangan umum. Adapun manfaat yang diharapkan peneliti adalah sebagai berikut:

1. Manfaat Secara teoritis

8 Andi Prastowo, Pengembangan Bahan Ajar Tematik Tinjauan Teoritis dan Praktis (Jakarta: Kencana, 2014), 342. 
JIIPSI: Jurnal Ilmiah Ilmu Pengetahuan Sosial Indonesia Nomor 1 Volume 1 Tahun 2021, hal 1-12

Hasil penelitian ini diharapkan dapat memberi sumbangsih pikiran terhadap khazanah ilmiah dalam rangka memanfaatkan Media Pembelajaran Audio Visual secara maksimal di SMP Negeri 1 Jenangan.

2. Manfaat Secara praktis

Hasil penelitian ini diharapkan dapat bermanfaat bagi:

a. Bagi Lembaga Pendidikan

Bagi SMP Negeri 1 Jenangan hasil penelitian ini dapat dijadikan sebagai suatu prestasi tersendiri dan juga sebagai masukan yang konstruktif dalam rangka pemanfaatan IPTEK secara lebih maksimal di SMP Negeri 1 Jenangan.

b. Bagi Pendidik

Hasil pembahasan penelitian ini dapat dijadikan sebagai penambahan wawasan dalam rangka meningatkan kualitas pendidikan.

c. Bagi Peneliti yang akan datang

Hasil penelitian ini diharapkan dapat dijadikan rujukan bagi peneliti yang akan datang.

\section{METODE PENELITIAN}

Dalam Penelitian ini penulis menggunakan pendekatan kualitatif, karena dalam proses penelitian ini, peneliti mengharapkan mampu memperoleh data yang mendalam dari orang-orang yang diamati baik secara tertulis maupun lisan. Sehingga penelitian ini mampu mendapatkan hasil informasi Studi dalam situasi alamiah (naturalist icinquiry), Desain penelitian kualitatif bersifat alamiah, dalam arti peneliti tidak berusaha untuk memanipulasi latar penelitian, melainkan melakukan studi terhadap suatu fenomena dalam situasi di mana fenomena tersebut ada. Fokus penelitian dapat berupa orang, kelompok, program, pola hubungan ataupun interaksi, dan kesemuanya dilihat dalam konteks alamiah (apa adanya). ${ }^{9}$

Teknik pengumpulan data adalah sebuah cara untuk mendapatkan data-data di lapangan agar hasil penelitian dapat bermanfaat dan menjadi teori baru atau penemuan baru. Dengan tanpa adanya cara untuk mengumpukan data-data yang ingin diteliti maka apa yang menjadi tujuan penelitian akan sia-sia. Adapun teknik pengumpulan data yang dimaksud seperti observasi, wawancara, dan dokumentasi. Dengan cara tersebut sebuah penelitian akan mendapatkan sebuah data yang valid dan dapat diuji. ${ }^{10}$ Penggunaan teknik pengumpulan data ini peneliti harus hadir di lokasi penelitian untuk mengetahui kondisi/keadaan yang sebenarnya di SMP Negeri 1 Jenangan dalam Pembelajaran IPS Terpadu. Teknik pengumpulan data dalam penelitian ini adalah Observasi, wawancara dan dokumentasi setelah data terkumpul peneliti menganalisis data dengan langkahlangkah Analisis Model Miles dan Huberman Menurut Miles and Huberman ada

9 Seto Mulyadi, Metode Penelitian Kualitatif dan Mixed Method (Depok: PT Raja Grafindo Persada, 2019), 54.

${ }^{10}$ Umar Sidiq, Metode Penelitian Kualitatif di Bidang Pendidikan (Ponorogo: CV Nata Karya, 2019), 58. 
tiga serangkaian kegiatan yang dilakukan dalam analisis data yang terdiri dari Data reduction (reduksi data), Data Display (Penyajian data), Conclusion Drawing/Verivication.

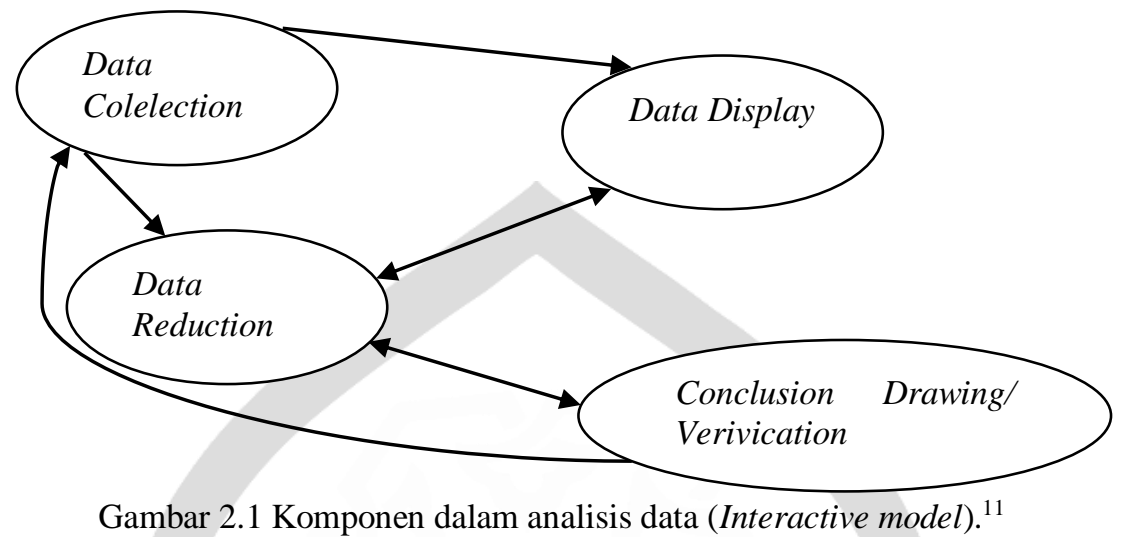

Ditinjau dari jenisnya penelitian ini adalah jenis penelitian studi kasus. Studi kasus adalah penelitian yang meneliti suatu fenomena terbaru secara utuh dan mendalam pada kondisi alamiah (naturalist icinquiry), melalui berbagai sumber data. Peneliti akan mengarahkan penelitian kualitatif studi kasus ini pada Media Pembelajaran Audio Visual dalam Mengembangkan Motivasi Belajar Sisiwa Pada Mata Pelajaran IPS Terpadu di SMP Negeri 1 Jenangan.

\section{HASIL DAN PEMBAHASAN}

AECT (Association of Education and Communication Technology) memberi standart tentang pemanfaatan media sebagai semua model dan perantara yang dimanfaatkan sebagai penyalur informasi dan pesan dengan bentuk suara dan gambar $^{12}$ Menurut hasil wawancara yang dilakukan peneliti di lapangan menunjukkan bahwa penggunaan media audio visual pada mata pelajaran IPS Terpadu merupakan penggunaan media yang bagus dan efisien, sebagai usaha untuk menunjang pembelajaran dan menumbuhkan motivasi belajar siswa pada mata pelajaran IPS Terpadu, sehingga diharapkan siswa mendapatkan hasil yang memuaskan setelah penerapan media audio visual pada mata pelajaran IPS Terpadu, siswa bisa memahami betul materi dan juga bisa menumbuhkan semangat dalam kegiatan belajar serta di harapkan agar siswa mampu mengeluarkan semua pendapatnya, dan mampu menjawab pertanyaan-pertanyaan guru.

Penggunaan media audio visual di SMP Negeri 1 Jenangan dengan media video dan power point, yang diharapkan mampu untuk menjadikan pembelajaran IPS Teradu lebih menarik lagi dan motivasi belajar siswa lebih meningkat dalam belajar, terlihat dari keadaan siswa yang antusias selama proses pembelajaran dan keaktifan siswa di dalamkelas dalam mengikuti pembejaran IPS Terapdu.Dalam penggunaan media audio visual pada mata pelajaran IPS Terpadu

${ }^{11}$ Sugiyono, Metode Penelitian Pendidikan Pendekatan Kuantitatif Kualitatif dan R\&D (Bandung: Alfabeta, 2012), 338.

${ }^{12}$ Azhar Arsyad, Media Pembelajaran (Depok: PT Raja Grafindo Persada, 2013), 5. 
JIIPSI: Jurnal Ilmiah Ilmu Pengetahuan Sosial Indonesia Nomor 1 Volume 1 Tahun 2021, hal 1-12

di SMP Negeri 1 Jenangan memiliki manfaat dan memudahkan bagi guru dan para siswa. Diantara hasil dari penggunaan media audio visual terlihat dari observasi yang dilakukan peneliti antusias siswa dalam mengikuti proses pembelajaran IPS Terpadu sangat tinggi, siswa menjadi aktif di dalam kelas selama proses pembelajaran, dan prestasi siswa yang meningkat, ditunjukkan dengan nilai-nilai hasil ulangan yang bagus.

Inilah salah satu upaya yang dilakukan guru mata pelajaran IPS Terpadu untuk meningkatkan pemahaman siswa dalam memahami materi-materi pelajaran IPS Terpadu, dan usaha ini juga tidak terlepas dari tersedianya sarana dan prasarana untuk menunjang kegiatan belajar yang ada disekolah, salah satunya media audio visual yang digunakan untuk pembelajaran pada mata pelajaran IPS Terpadu di SMP Negeri 1 Jenangan dan berdasarkan observasi yang dilakukan oleh peneliti usaha SMP Negeri 1 Jenangan dalam menyediakan sarana dan prasarana untuk program pembelajaran cukup baik, di SMP Negeri 1 Jenangan ini sarana di dalam kelas sudah cukup layak dan mumpuni, diantaranya yaitu media audio visual dengan adanya alat untuk memutar video seperti LCD dan TV. Dengan demikian guru tidak ada kesulitan dalam menerapkan media dalam kegiatan belajar mengajar.

\section{Perencanaan Pemanfaatan Media Pembelajaran Audio Visual di SMP Negeri 1 Jenangan}

Proses perencanaan pemanfaatan media pembelajaran yang guru siapkan mampu menyumbangkan arah tujuan dan pemahaman untuk peserta didik dan guru yang kemudian dapat membantu peserta didik untuk menyadari mengenai tujuan-tujuan yang tersirat dalam tugas-tugas pembelajaran yang harus mereka laksanakan. Seorang guru professional sebelum melaksanakan tugas mengajar harusnya mempunyai persiapan berupa perenrencanaan termasuk dalam hal media yang akan mereka manfaatkan harus dipersiapkan dengan tepat apakah media yang dimanfaatkan mampu memenuhi kebutuhan pserta didik atau tidak.

Arief S. Sadiman Ada beberapa langkah yang perlu diperhatikan dalam pemanfaatan media pembelajaran di kelas ini, yaitu: Pertama, persiapan guru: pada langkah ini guru menetapkan tujuan yang akan dicapai melalui media pembelajaran sehubungan dengan pelajaran (materi) yang akan dijelaskan berikut dengan strategi-strategi penyampaiannya. Kedua, persiapan kelas: pada langkah ini bukan hanya menyiapkan perlengkapan, tetapi juga mempersiapkan siswa dari sisi tugas, misalnya agar dapat mengikuti, mencatat, menganalisis, mengeritik, dan lain-lain. Ketiga, penyajian: penyajian media pembelajaran sesuai dengan karakteristiknya. Keempat, langkah lanjutan dan aplikasi: sesudah penyajian perlu ada kegiatan belajar sebagai tindak lanjutnya, misalnya diskusi, laporan, dan tugas lain. ${ }^{13}$

Perencanaan pemanfaatan media pembelajaran di SMP Negeri 1 Jenangan sudah berjalan cukup baik walaupun dilaksanakan sepenuhnya tetapi masih belum sesuai standart. Berdasarkan semua data mengenai proses perencanaan

${ }^{13}$ Yudhi Munadi, Media Pembelajaran (Jakarta Selatan: REFRENSI, 2013), 208. 
pemanfaatan media pembelajaran sesuai yang disampaikan di atas, dapat dimengerti bahwa kegiatan perencanaan media pembelajaran IPS Terpadu di sekolah antara lain adalah: (1) menyesuaikan dengan kurikulum 2013, (2) mengorganisasikan dengan materi dan alokasi waktu, (3) membaca situasi dan kondisi kelas, (4) memilih dan menetapkan daftar media yang dibutuhkan.

Sejalan dengan teori dan hasil wawancara yang dilakukan peneliti dapat dimengerti bahwa ketika memanfaatkan media audio visual seharusnya disesuikan dengan materi yang cocok dan menggunakan media audio visual yang sesuai dengan materi pelajaran IPS Terpadu, Sehingga saat guru melaksanakan proses belajar mengajar, peserta didik mampu menerima penyampaian dari guru, dan tujuan dari pembelajaran bisa tercapai, dalam proses belajar mengajar tidak hanya guru yang terus menjelaskan tetapi peserta didik juga harus mampu menyampaikan pemahan yang mereka dapat saat proses belajar mengajar, sehingga mucul semngat motivasi belajar dalam diri peserta didik dalam pembelajaran IPS Terpadu.

\section{Langkah-langkah Pemanfaatan Media Pembelajaran Audio Visual di SMP Negeri 1 Jenangan}

Berdasarkan pendapat dari Sri Anita yang menyatakan bahwa agar media dapat digunakan secara efektif dan efisien, maka langkah utama yang perlu diikuti dalam menggunakan media, yaitu: Persiapan awal sebelum memanfaatkan media, Pelaksanaan pemanfaatan media, Tahap Evaluasi, Tindak lanjut. ${ }^{14}$

Sesuai hasil observasi dan wawancara yang dilaksanakan peneliti dengan semua guru mata pelajaran IPS Terpadu dan beberapa siswa, maka peneliti pahami bahwa proses persiapan yang dilaksanakan dalam pemanfaatan media audio visual adalah guru merencanakan silabus pembelajaran, menyusun RPP, menyalakan LCD proyektor menyampaikan indikator pembelajaran, menyampaikan kompetensi dasar, menyampaikan tujuan pembelajaran, dan memberitahukan kepada siswa bahwa mereka akan melakukan proses pembelajaran secara berkelompok dengan materi yang ditayangkan di LCD Proyrktor, tetapi sebelum itu mereka diminta untuk memperhatikan tayangan video/film pendek yang berkaitan materi pembelajaran, dengan durasi waktu kurang lebih delapan menit dan menuruh peserta didik untuk mempersiapkan diri dalam melakukan kegiatan diskusi secara berkelompok dilanjutkan dengan kegiatan presentasi lalu diakhir pembelajaran peserta didik diminta untuk menyampaikan permasalahan atau materi yang kurang dipahami untuk di terangkan lagi oleh pendidik.

Berdasarkan data observasi, wawancara dan dokumentasi tentang pemanfaatan media audio visual pada mata pelajaran IPS Terpadu di SMP Negeri 1 Jenangan dan teori dari Sri Anita tentang langkah-langkah yang harus dilakukan oleh guru dalam memanfaatkan media audio visual supaya proses belajar mengajar berlangsung secara kondusif. Sudah sesuai dengan prosedur dengan adanya suatu perencanaan dan persiapan sebelumnya secara matang. Pelaksanaan yang

\footnotetext{
${ }^{14}$ Sri Anita, Media Pembelajaran (Surakarta: FKIP UNS, 2009), 82-85.
} 
JIIPSI: Jurnal Ilmiah Ilmu Pengetahuan Sosial Indonesia Nomor 1 Volume 1 Tahun 2021, hal 1-12

terorganisir dan melakukan tahap evaluasi sebagai upaya dalam melihat tingkat keberhasilan dari proses yang dilaksanakan dan sebagai metode untuk memperoleh respon sebagai bahan tindak lanjut berikutnya, oleh sebab itu yang perlu diperhatikan dalam pemanfaatan media audio visual sebaiknya media yang dimanfaatkan sudah biasa dan tidak asing lagi bagi guru maupun peserta didik, media yang dimanfaatkan dapat menyalurkan pemahaman informasi dan sebaiknya media yang dimanfaatkan dapat mengembanggkan motivasi belajar peserta didik.

\section{Kelebihan dan Kekurangan Pemanfaatan Media Pembelajaran Audio Visual}

Perlu disadari bahwa media pembelajaran ini mempunyai banyak keunggulan dibandingkan dengan media pembelajaran yang lainnya. Akan tetapi penggunaan tersebut tidak berarti apa-apa apabila guru tidak dapat mengoperasikan atau menggunakan. Apabila mampu mengoperasikannya pun, tetapi tidak sesuai dengan materi yang diajarkan maka akan juga berdampak buruk pada proses belajar mengajar yang dijalankannya. ${ }^{15}$

Pelaksaanaan Penggunaan media audio visual dalam pembelajaran memberikan dampak baik bagi peserta didik, peserta didik merasakan suasana pembelajaran yang baru, suasana kelas menjadi lebih komunikatif karena materi yang di tampilkan dikemas dengan slide-slide powe point mampu menarik semua perhatian sisiwa sehingga, pembelajaran menjadi menyenangkan sehingga peserta didik menjadi lebih termotivasi dalam mengikuti pembelajaran. Proses pemanfaatan media pembelajran audio visual di SMP Negeri 1 Jenangan memiliki beberapa faktor penghambat utama yaitu bahwa yang sering dialami oleh guru dalam menggunakan media audio visual adalah masalah waktu. Persiapan guru dalam menyiapkan media ini selalu menyita waktu belajar, akhirnya menyebabkan waktu pembelajaran kurang efisien karena waktu belajarnya menjadi kurang sehingga tidak optimal dalam penyampaian materi pembelajaran dan sering mengambil waktu belajar mata pelajaran berikutnya setelah mata pelajaran IPS Terpadu.

Sesuai dengan yang dikatakan oleh Abdul Majid dalam bukunya strategi pembelajaran, beliau mengatakan salah satu strategi memotivasi siswa adalah gunakan strategi dan pembelajaran yang berbeda melaksanakan hal yang sama secara berkelanjutan dapat membuat kejenuhan dan menghilangkan semangat belajar. Peserta didik yang jenuh akan membuat proses belajar terganggu. Hal baru dapat membuat peserta didik tetap tenang dan senang. Diselingi dengan hal yang berbeda dengan menerapkan strategi belajar yang bervariasi di dalam kelas. Misalnya membuat pembagian kelompok, diskusi, debat, studi kasus, simulasi, presentasi dengan media audio visual dengan menampilkan slide show. ${ }^{16}$

Dari hasil wawancara, observasi dan dokumentasi di SMP Negeri 1 Jenangan, diperoleh bahwa dalam proses pemanfaatan media pembelajaran audio visual

${ }^{15}$ Suprijanto, Teknologi Pendidikan (Semarang: Rasail, 2005), 175.

${ }^{16}$ Abdul Majid, Strategi Pembelajaran (Bandung: PT Remaja Rosdakarya, 2016), 321. 
peserta didik menjadi termotivasi dan lebih tertarik ketika proses belajar berlangsung, peserta didik tidak mudah bosan dengan media yang dimanfaatkan oleh guru, karena dalam hal ini guru memanfaatkan media secara beragam, sehingga peserta didik semakin merasa senang, dan lebih mudah memahami materi.

\section{PENUTUP}

Berdasarkan data wawancara, observasi dan dokumentasi yang telah diperoleh selama penelitian ini dapat peneliti pahami pemanfaatan media pembelajaran audio visual khususnya pada mata pelajaran IPS Terpadu di SMP Negeri 1 Jenangan sudah menjadi semacam candu bgi siswa, hal tersebut dilihat oleh peneliti saat observasi siswa terlihat antusias dengan materi yang disampaikan menggunakan media audio visual dan sebaliknya siswa akan malas memperhatikan materi jika penyampaian materi hanya dengan metode ceramah, maka para guru IPS Terpadu berusaha untuk memenuhi rasa candu para siswa tersebut dengan memanfaatkan pembelajaran media audio visual dalam setiap pembelajaran.

1. Pemanfaatan dan pelaksanaan media pembelajaran audio visual di SMP Negeri 1 Jenagan sudah cukup baik hal tersebut terjadi karena SDM khususnya pendidik di SMP Negeri 1 Jenangan sudah terbiasa menerapkan pembelajaran dengan bantuan media audio visual tentu hal tersebut juga ditunjang oleh kelengkapan sarana dan prasarana yang ada di dalam setiap kelas yang sangat memadai.

2. Kelebihan dan kekurangan dari pemanfaatan media pembelajaran audio visual di SMP Negeri 1 Jenangan tentu memiliki kendala yang dihadapi yaitu masalah teknis dalam pelaksanaannya yang berdampak pada waktu pembelajaran namun hal tersebut bisa disiasati oleh pendidik dengan melakukan persiapan penggunaan media pembelajaran audio visual sebelum jam pelajaran dimulai.

3. Dampak dari pemanfaatan media pembelajaran audio visual di SMP Negeri 1 Jenangan yaitu mampu mengembangkan motivasi belajar siswa khususnya pada mata pelajaran IPS Terpadu hal tersebut terungkap berdasarkan data wawancara, observasi dan dokumentasi yang dilakukan peneliti secara tekun dan teliti.

\section{DAFTAR PUSTAKA}

Anita, Sri. (2009). Media Pembelajaran. Surakarta: FKIP UNS.

Arsyad, Azhar. (2013). Media Pembelajaran. Depok: PT Raja Grafindo Persada.

Audie, Nurul. (2019). "Peran Media Pembelajaran Meningkatkan Hasil Belajar Peserta Didik", Jurnal Universitas Sultan Ageng Tirtayasa, 587.

Dendi Tri Suarno, Sukirno. (2015). "Pengembangan Media Pembelajaran IPS dengan Tema Pemanfaatan dan Pelestarian Sungai untuk Siswa Kelas VII SMP," Harmoni Sosial, 117. 
JIIPSI: Jurnal Ilmiah Ilmu Pengetahuan Sosial Indonesia Nomor 1 Volume 1 Tahun 2021, hal 1-12

Falahudin, Iwan. (2014) Pemanfaatan Media Pembelajaran. Jurnal Lingkar Widyaiswara, 104.

Khanifatul. (2017). Pembelajaran Inovatif. Jogjakarta: AR-Ruzz Media.

Majid, Abdul. (2016). Strategi Pembelajaran. Bandung: PT Remaja Rosdakarya.

Mulyadi, Seto Mulyadi. (2019). Metode Penelitian Kualitatif dan Mixed Method. Depok: PT Raja Grafindo Persada.

Munadi, Yudhi. (2013). Media Pembelajaran. Jakarta Selatan: REFRENSI.

Prastowo, Andi. (2014). Pengembangan Bahan Ajar Tematik Tinjauan Teoritis dan Praktis. Jakarta: Kencana.

Rosyid, Moh Ziful Etall. (2019). Ragam Media Pembelajaran. Malang: Literasi Nusantara.

Sidiq, Umar. (2019). Metode Penelitian Kualitatif di Bidang Pendidikan. Ponorogo: CV Nata Karya.

Sugiyono. (2012). Metode Penelitian Pendidikan Pendekatan Kuantitatif Kualitatif dan $R \& D$. Bandung: Alfabeta.

Suprijanto. (2005). Teknologi Pendidikan. Semarang: Rasail.

Wahidmurni. (2017). Metodologi Pembelajaran IPS. Yogyakarta: AR-Ruzz Media. 